\title{
Evaluating DC Voltage Temperature Coefficient of a Multicrystalline Module in Actual Environmental Conditions of Western Rajasthan, India
}

\author{
Shalini Garg \\ Government Polytechnic College \\ Jodhpur, India
}

\author{
Arun J. B. \\ Government Polytechnic College \\ Ajmer, India
}

\begin{abstract}
Solar irradiance and cell temperature are the two most important parameters governing the efficiency of PV power plant. This paper presents simultaneous impact of cell temperature and the irradiance falling on the plane of solar panels- POA (Plane of Array Irradiance) on the dc voltage $\left(\mathrm{V}_{\mathrm{dc}}\right)$ of a multicrystalline Photovoltaic(PV) module, one of the most important parameter governing dc power and hence efficiency of (PV) power plant. In contrast to existing literature which specify negative temperature coefficient for $\mathrm{V}_{\mathrm{dc}}$ above $25^{\circ} \mathrm{C}$ cell temperature, analysis in actual environmental conditions of Western Rajasthan for a grid connected multicrystalline $\mathrm{PV}$ power plant shows that $\mathrm{V}_{\mathrm{dc}}$ has about $-0.431 \% /{ }^{\circ} \mathrm{C}$ temperature coefficient for cell temperature greater than $49^{\circ} \mathrm{C}$ and not $25^{\circ} \mathrm{C}$ as evaluated in laboratory. Moreover, voltage for cell temperature in the range of 49$60^{\circ} \mathrm{C}$ is far greater than voltage at $25-45^{\circ} \mathrm{C}$. Further at very high cell temperature of about $49^{\circ} \mathrm{C}$ dc voltage $\left(\mathrm{V}_{\mathrm{dc}}\right)$ reaches a point of saturation attaining $85 \%$ of its maximum rated value. It decreases slightly by about $4 \%$ as cell temperature increases from $49^{\circ} \mathrm{C}$ to $60^{\circ} \mathrm{C}$ but as soon as sun begins to descent, cell temperature starts reducing and $\mathrm{V}_{\mathrm{dc}}$ starts increasing, maintaining nearly constant value in the range of $80-85 \%$ of its maximum rated value for about 6-8 hours. If cell temperature is less than about $45^{\circ} \mathrm{C}$, neither $\mathrm{V}_{\mathrm{dc}}$ reaches point of saturation nor does it attain constant value. Thus, high cell temperature has overall positive effect on dc voltage of a multicrystalline grid connected PV power plant. Western Rajasthan being blessed with high temperature and high insolation for 6-7 hours in a day for about eight months has the capability of high energy yield as dc power is directly proportional to dc voltage.
\end{abstract}

\section{General Terms}

Solar Irradiance, DC output voltage, Grid connected PV power plant

\section{Keywords}

Multicrystalline; high cell temperature; temperature coefficient; Plane of Array Irradiance(POA); Western Rajasthan.

\section{INTRODUCTION}

PV modules are rated at STC conditions that is at, Irradiance- $1000 \mathrm{~W} / \mathrm{m}^{2}$; Module Temperature- $25^{\circ} \mathrm{C}$; Air Mass1.5; NOCT (Nominal Operating Cell Temperature) $47^{\circ} \mathrm{C}$; Operating Temperature $-40^{\circ} \mathrm{C}$ to $+85^{\circ} \mathrm{C}$. Literature and research papers all show negative effect of cell temperature above $25^{\circ} \mathrm{C}[1,2]$. The temperature coefficient for both voltage and power is negative and is different for different types of cells. The temperature coefficient of $\mathrm{V}_{\mathrm{oc}}$ (open circuit voltage) as specified by the manufacturer for the module used in the analysis is $-0.353 \% /{ }^{\circ} \mathrm{K}$ for cell temperature greater than $25^{\circ} \mathrm{C}$ or $298^{\circ} \mathrm{K}$ as shown in table 1 . This means that at cell temperature $30{ }^{\circ} \mathrm{C}, \mathrm{V}_{\text {oc }}$ will be $37.67[1-0.00353 * 5]$ that is $37.005 \mathrm{~V}$ instead of $37.67 \mathrm{~V}$ as specified at $25^{\circ} \mathrm{C}$.

In Western Rajasthan, high ambient temperature about 30$40^{\circ} \mathrm{C}$ persists for about eight months [3]. This paper illustrates comprehensive study of real field data to analyse the effect of high cell temperature and POA on the dc voltage of a grid connected multicrystalline module and to estimate temperature coefficient for multicrystalline module in real field conditions which is far different from laboratory conditions. The work done is extension of my previous two papers $[4,5]$. In previous paper [4] dc voltage was analysed with respect to ambient temperature and GHI (Global Horizontal Irradiance) but results show that $\mathrm{V}_{\mathrm{dc}}$ has better correlation with cell temperature and POA. The results are significant and consistent with the previous results. The parameters of the module used in the analysis are specified in table 1 .

Table 1. The specifications of the multicrystalline PV module at 5 MW grid Connected Power Plant

\begin{tabular}{|l|l|l|}
\hline $\begin{array}{l}\text { S. } \\
\text { No }\end{array}$ & Electrical Characteristics & Values \\
\hline 1. & Maximum power $\mathrm{P}_{\text {mpp }} / \mathrm{P}_{\max }$ & $247.39 \mathrm{~W}$ \\
\hline 2. & Voltage at $\mathrm{P}_{\max }, \mathrm{V}_{\mathrm{mpp}}$ & $30.64 \mathrm{~V}$ \\
\hline 3. & Current at $\mathrm{P}_{\max }, \mathrm{I}_{\mathrm{mpp}}$ & $8.07 \mathrm{~A}$ \\
\hline 4. & Open circuit voltage $\mathrm{V}_{\mathrm{oc}}$ & $37.67 \mathrm{~V}$ \\
\hline 5. & Short circuit current $\mathrm{I}_{\mathrm{sc}}$ & $8.26 \mathrm{~A}$ \\
\hline 6. & Temperature coefficient of $\mathrm{P}_{\max }$ & $-0.447 \%{ }^{\circ} \mathrm{K}$ \\
\hline 7. & Temperature coefficient of $\mathrm{V}_{\mathrm{oc}}$ & $-0.353 \%{ }^{\circ} \mathrm{K}$ \\
\hline 8. & Temperature coefficient of $\mathrm{I}_{\mathrm{sc}}$ & $0.104 \% /{ }^{\circ} \mathrm{K}$ \\
\hline 9. & Power Tolerance & $-0 /+5 \mathrm{~W}$ \\
\hline 10. & Fuse rating & $15 \mathrm{~A}$ \\
\hline 11. & Maximum System Voltage & $1000 \mathrm{~V}$ \\
\hline 12. & Maximum array voltage & $\begin{array}{l}735.36 \mathrm{~V} \\
(24 * 30.64)\end{array}$ \\
\hline 13. & Maximum array current & $\begin{array}{l}161.4 \mathrm{~A} \\
(8.07 * 20)\end{array}$ \\
\hline 14. & Maximum array power & $\begin{array}{l}118.687 \mathrm{KW} \\
\left(735.36^{*} 161.4\right)\end{array}$ \\
\hline
\end{tabular}




\section{METHODOLOGY}

Based on the real field data, temperature coefficient has been evaluated for extremely high cell temperature which exists during month of May to July, vide data from May 2016 to July 2016 of a 5 MW grid connected multicrystalline PV power plant located at Ramgarh, in district Jaisalmer of Western Rajasthan. To compare the dc voltage at various temperature graphs corresponding to different temperatures have been compiled on a single graph and detail view of December 2015 have also been included, considering overall one-year data over the period of September 2015-August 2016.

2.1The analysis of dc voltage is based on the average reading of five array with maximum rated dc voltage being equal to $735.36 \mathrm{~V}$.

2.2Simultaneous effect of POA and cell temperature are visualised on the true scale, by diving the entire analyses into two parts-

- With increasing POA as sun rises from about 7:15 to $1: 00 \mathrm{pm}$.

- With decreasing POA, as sun begins to decent from about 1:00pm to 5:00pm.

Distinct effects are seen with increasing POA and decreasing POA. VDC-U, AMB-U and CELL-U are the curves for $\mathrm{V}_{\mathrm{dc}}$, ambient temperature and cell temperature respectively with increasing POA while, VDC-D, , AMB-D, CELL-D are the curves for $\mathrm{V}_{\mathrm{dc}}$, ambient temperature and cell temperature respectively with decreasing POA. The short forms are followed by the related date for example VDC-D 13-05-16 means dc voltage with decreasing POA for $13^{\text {th }}$ of May 2016.

2.3To evaluate temperature coefficient for $V_{d c}$ following assumptions are made-

i. Let $\Delta \mathrm{X}$ represent time duration that is $\Delta \mathrm{X}=\mathrm{X}_{2}-\mathrm{X}_{1}$ where $X_{1}$ is the time when $V_{d c}$ attains maximum value(around 10:00am) and $X_{2}$ is the time when POA is maximum $\sim 1: 00 \mathrm{pm}$.

ii. Let $\Delta \mathrm{V}, \Delta \mathrm{POA}, \Delta \mathrm{T}_{\mathrm{c}}$, represent change in $\mathrm{V}_{\mathrm{dc}}, \mathrm{POA}$ and cell temperature respectively with increasing POA in time duration $\Delta \mathrm{X}$.

- $\quad \Delta \mathrm{V}=\mathrm{V}_{2}-\mathrm{V}_{1} ; \mathrm{V}_{1}=\mathrm{V}_{\mathrm{dc}}$ at time $\mathrm{X}_{1} ; \mathrm{V}_{2}=\mathrm{V}_{\mathrm{dc}}$ at time $\mathrm{X}_{2}$

- $\quad \triangle \mathrm{POA}=\mathrm{POA}_{2}-\mathrm{POA}_{1} ; ; \mathrm{POA}_{1}=\mathrm{POA}$ at time $\mathrm{X}_{1}$; $\mathrm{POA}_{2}=\mathrm{POA}$ at time $\mathrm{X}_{2}$;

- $\quad \Delta \mathrm{T}_{\mathrm{c}}=\mathrm{T}_{\mathrm{c} 2}-\mathrm{T}_{\mathrm{cl}} ; \mathrm{T}_{\mathrm{cl}}$ is cell temperature at time $\mathrm{X}_{1}$; $T_{c 2}$ is cell temperature at $X_{2}$

iii. Let $\mathrm{V}_{\mathrm{r}}$ represent $\mathrm{V}_{\mathrm{dc}}$ in $\%$ with respect to maximum rated dc voltage;

- $\quad \mathrm{V}_{\mathrm{r}}=\left(\mathrm{V}_{\mathrm{dc}} / \mathrm{V}_{\text {rated }}\right) * 100$.

iv. Let $\Delta \mathrm{V}_{\mathrm{u}}$, represent $\%$ change in $\mathrm{V}_{\mathrm{dc}}$, with respect to their maximum rated value in the time interval $\left(\mathrm{X}_{2}-\right.$ $\mathrm{X}_{1}$ ) when POA is increasing continuously.

- $\Delta \mathrm{V}_{\mathrm{u}}=\{\Delta \mathrm{V} /$ maximum rated dc voltage of the array $\}$ $* 100$.

v. Let $\mathrm{V}_{\alpha}$ represent Temperature coefficient in $\% /{ }^{\circ} \mathrm{C}$;

- $\mathrm{V}_{\alpha}=\left(\Delta \mathrm{V}_{\mathrm{u}} / \Delta \mathrm{T}_{\mathrm{c}}\right)$
2.4 Weather monitoring station, pyranometer, and SCADA (Supervisory Control and Data Acquisition) is used to record and store various data.

2.5 The irradiance considered is the irradiance incident on the plane of the array- POA

\section{EXPERIMENTAL DATA ANALYSIS} 3.1 Effect of high cell temperature on $V_{d c}$

The effect of high cell temperature on $V_{\mathrm{dc}}$ has been analysed by considering three different dates of the month having very high temperature for long duration. The time with corresponding POA over the interval when $\mathrm{V}_{\mathrm{dc}}$ is reducing is marked in figure1.

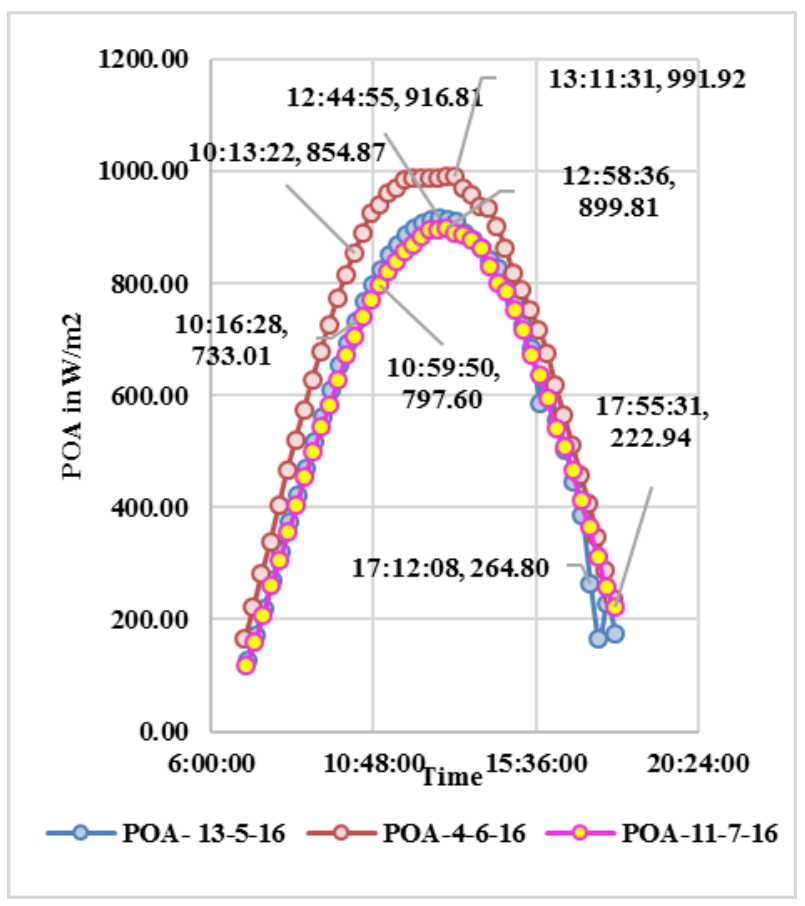

Figure 1- Variation of POA in $\mathrm{W} / \mathrm{m}^{2}$ with time for 13-5-16; 4-6-16; 11-7-16

\subsubsection{Analysis for $13^{\text {th }}$ of May 2016}

Starting from the wake up voltage as soon as light falls on module, $\mathrm{V}_{\mathrm{dc}}(\mathrm{VDC}-13-5-16)$ drops rapidly as Sun starts rising [6]. This is followed by rapid increase in $V_{d c}$ with increasing POA until ambient temperature is less than $38^{\circ} \mathrm{C}$ and cell temperature is less than $49^{\circ} \mathrm{C}$. At this point it attains maximum value nearly $85 \%$ of its maximum rated value. Thereafter $\mathrm{V}_{\mathrm{dc}}$ starts reducing with increasing POA and increasing ambient temperature but as soon as POA start reducing, $\mathrm{V}_{\mathrm{dc}}(\mathrm{VDC}-\mathrm{D}-13-5-16)$ starts increasing gradually although ambient temperature(AMB-D-13-5-16) continues to increase as depicted in figure 2 . The reason for this is clear from figure 3 , which shows that as soon as POA starts decreasing, cell temperature also begins to drop gradually, the result is gradual increase in $\mathrm{V}_{\mathrm{dc}}$. Thus, it is evident from figure 2 and 3 that it is the cell temperature which is governing the $\mathrm{dc}$ voltage and not the ambient temperature. For all further analysis only cell temperature is considered.

$\mathrm{V}_{\mathrm{dc}}$ remains constant from the time when POA is $733.01 \mathrm{~W} / \mathrm{m}^{2}$ to when POA drops to $264.80 \mathrm{~W} / \mathrm{m}^{2}$ that is from $10: 15$ to $17: 15$ for about six hours as shown in figure 1 and 3 . 


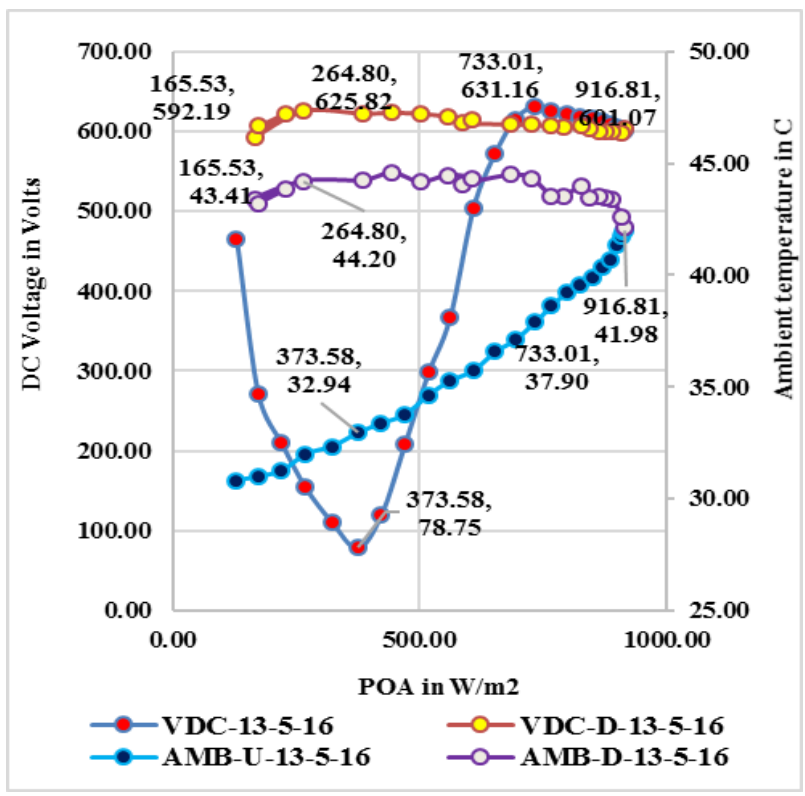

Figure 2- Variation of $\mathrm{V}_{\mathrm{dc}}$ and ambient temperature with POA for 13-05-16

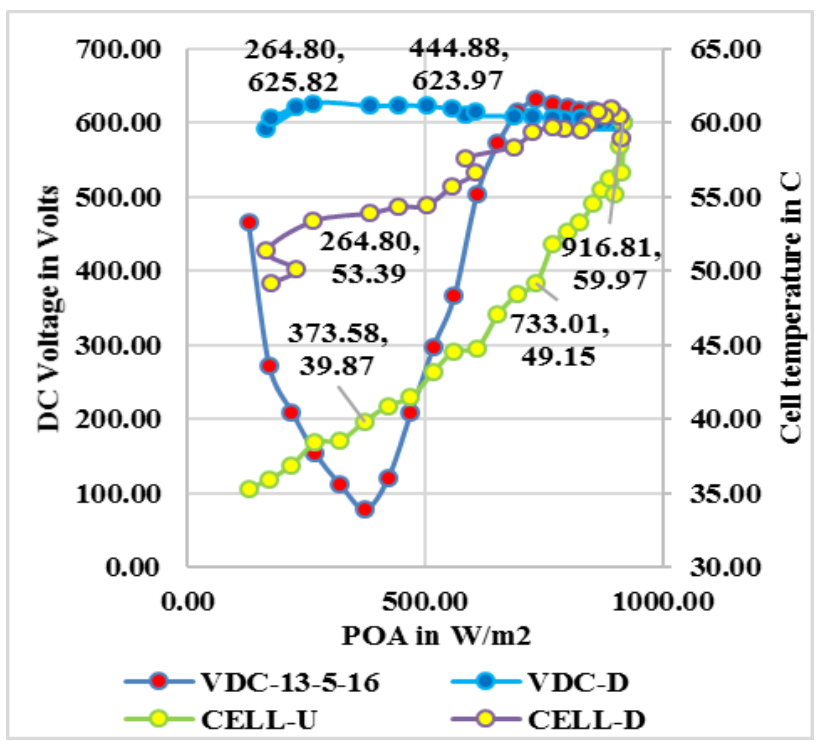

Figure 3- Variation of $V_{d c}$ and cell temperature with POA$13^{\text {th }}$ May 2016.

\subsubsection{Analysis for $4^{\text {th }}$ June and $11^{\text {th }}$ July}

The results are further verified by considering data for $4^{\text {th }}$ June and $11^{\text {th }}$ July 2016. Dates have been chosen randomly for display otherwise results are almost same for all dates for the month of May, Ju ne and July. The graph in figure 4 clearly shows that $\mathrm{V}_{\mathrm{dc}}$ reduces slightly with increasing POA(VDC-U) as soon as it attains $85 \%$ of its maximum rated value but again increases with decreasing POA(VDC-D) that is from 596.04V to $627.88 \mathrm{~V}$ for $4^{\text {th }}$ June and from $613.57 \mathrm{~V}$ to $630.21 \mathrm{~V}$ for $11^{\text {th }}$ July, maintaining nearly constant value for more than 7 to 8 hours.

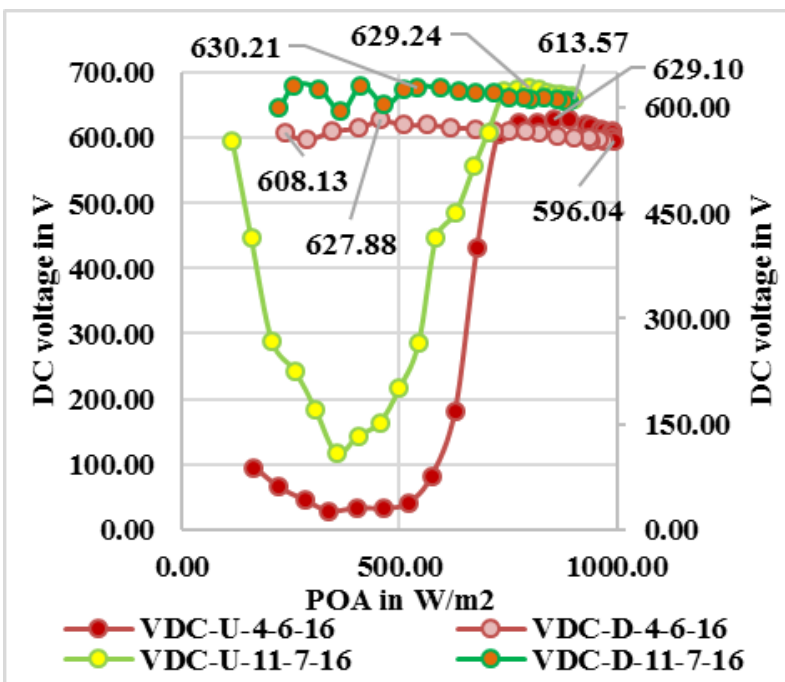

Figure 4- Variation of $V_{d c}$ and cell temperature for $4^{\text {th }}$ June and $11^{\text {th }}$ July with POA

\subsubsection{Evaluation of temperature coefficient}

Detailed view of figure 4 only for the duration when $V_{d c}$ is decreasing is shown in figure 5 showing that $\mathrm{V}_{\mathrm{dc}}$ decreases linearly with linear increase in cell temperature with increasing POA for cell temperature greater than $49^{\circ} \mathrm{C}$.

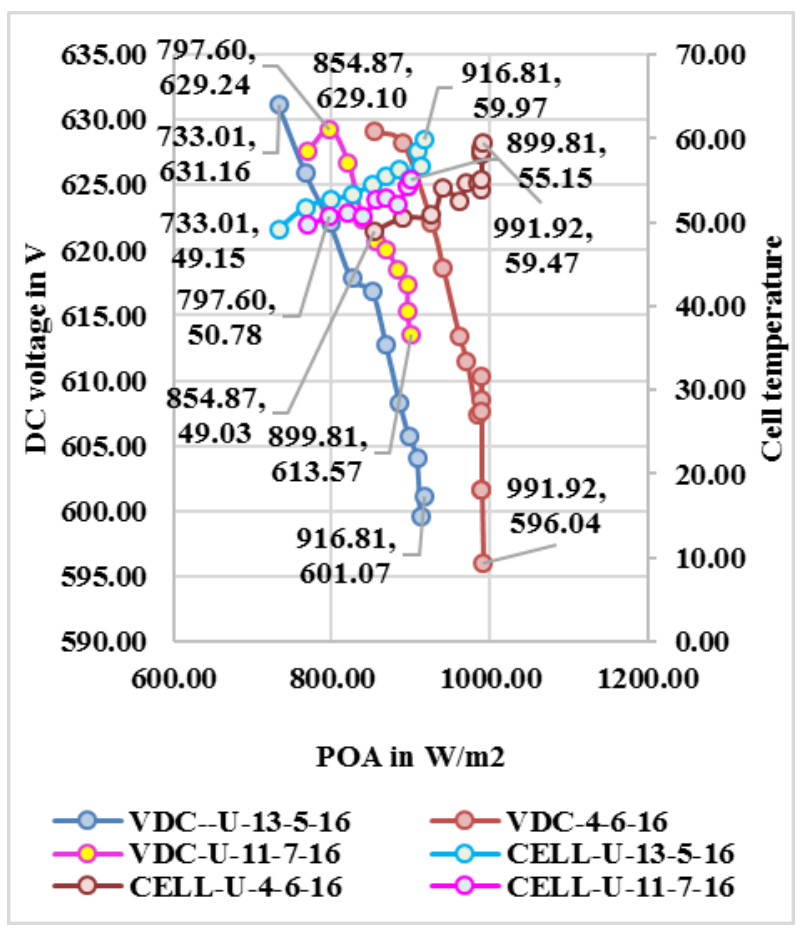

Figure 5- Graph showing detail view of decreasing $V_{d c}$ with increasing cell temperature.

In particular -

- $\quad$ For $13^{\text {th }}$ May- $\mathrm{V}_{\mathrm{dc}}$ decreases linearly from $631.16 \mathrm{~V}$ to $601.07 \mathrm{~V}$ as cell temperature increases linearly from $49.15^{\circ} \mathrm{C}$ to $59.97^{\circ} \mathrm{C}$.

- $4^{\text {th }}$ June $-\mathrm{V}_{\mathrm{dc}}$ decreases linearly from $629.10 \mathrm{~V}$ to $596.04 \mathrm{~V}$ as cell temperature increases linearly from $49.03^{\circ} \mathrm{C}$ to $59.47^{\circ} \mathrm{C}$.

- $\quad 11^{\text {th }}$ July $-\mathrm{V}_{\mathrm{dc}}$ drops from $629.24 \mathrm{~V}$ to $613.57 \mathrm{~V}$ as cell temperature increases from $50.78^{\circ} \mathrm{C}$ to $55.15^{\circ} \mathrm{C}$. 
The change in dc voltage with the corresponding change in cell temperature is evaluated in table 2. The temperature coefficient is also calculated for real time data as $V_{d c}$ decreases linearly with linear increase in cell temperature. Temperature coefficient, $\mathrm{V}_{\alpha}=\left(\Delta \mathrm{V}_{\mathrm{u}} / \Delta \mathrm{T}_{\mathrm{c}}\right)$ for -

- $\quad 13^{\text {th }}$ May- $\Delta \mathrm{V}_{\mathrm{u}}=-\{(631.16-601.07) / 735.36\} * 100=$ $-4.09 \% ; \Delta \mathrm{T}_{\mathrm{c}}=(59.97-49.15)=10.82^{\circ} \mathrm{C} ; \mathrm{V}_{\alpha}=-$ $(4.09 / 10.82)=-0.378 \% /{ }^{\circ} \mathrm{C}$;

- $\quad 4^{\text {th }}$ June $-\Delta \mathrm{V}_{\mathrm{u}}=-\{(629.10-596.04) / 735.36\} * 100=$ $-4.49 \% ; \Delta \mathrm{T}_{\mathrm{c}}=(59.47-49.03)=10.44{ }^{\circ} \mathrm{C} ; \mathrm{V}_{\alpha}=-($ $4.49 / 10.44)=-0.43 \% /^{\circ} \mathrm{C}$

- $\quad 11^{\text {th }}$ July $-\Delta \mathrm{V}_{\mathrm{u}}=-\{(629.24-613.57) / 735.36\} * 100$ $=-2.13 \% ; \Delta \mathrm{T}_{\mathrm{c}}=(55.15-50.78)=4.37^{\circ} \mathrm{C} ; \mathrm{V}_{\alpha}=-$ $(2.13 / 4.37)=-0.487 \% /^{\circ} \mathrm{C}$

- $\quad$ Average $\mathrm{V}_{\alpha}=\left(\mathrm{V}_{\alpha \mathrm{M}}+\mathrm{V}_{\alpha \mathrm{j}}+\mathrm{V}_{\alpha \mathrm{J}}\right) / 3=0.431 \% /^{\circ} \mathrm{C}$

Where $V_{\alpha M}, V_{\alpha j}, V_{\alpha J}$ are the temperature coefficient for specific dates in the month of May, June and July.

Similarly, $\Delta \mathrm{POA}_{\mathrm{a}}, \Delta \mathrm{T}_{\text {ca }}, \Delta \mathrm{V}_{\mathrm{a}}, \Delta \mathrm{V}_{\text {ua }}$ correspond to the average value of $\triangle \mathrm{POA}, \Delta \mathrm{T}_{\mathrm{c}}, \Delta \mathrm{V}, \Delta \mathrm{V}_{\mathrm{u}}$ respectively.

- $\Delta \mathrm{POA}_{\mathrm{a}}=\left(\Delta \mathrm{POA}_{\mathrm{M}}+\Delta \mathrm{POA}_{\mathrm{j}}+\Delta \mathrm{POA}_{\mathrm{J}}\right) / 3$

- $\Delta \mathrm{T}_{\mathrm{ca}}=\left(\Delta \mathrm{T}_{\mathrm{cM}}+\Delta \mathrm{T}_{\mathrm{cj}}+\Delta \mathrm{T}_{\mathrm{cJ}}\right) / 3$

- $\Delta \mathrm{V}_{\mathrm{a}}=\left(\Delta \mathrm{V}_{\mathrm{M}}+\Delta \mathrm{V}_{\mathrm{j}}+\Delta \mathrm{V}_{\mathrm{J}}\right) / 3$

- $\Delta \mathrm{V}_{\text {ua }}=\left(\Delta \mathrm{V}_{\mathrm{uM}}+\Delta \mathrm{V}_{\mathrm{uj}}+\Delta \mathrm{V}_{\mathrm{uJ}}\right) / 3$

Table 2- Evaluation of $\Delta \mathbf{V}_{\mathrm{u}}$

\begin{tabular}{|c|c|c|c|c|c|c|}
\hline$\stackrel{\stackrel{0}{*}}{\text { ڤే }}$ & $\begin{array}{l}\text { Time } \\
\text { interval }\end{array}$ & $\begin{array}{l}\text { POA in } \\
\mathrm{W} / \mathrm{m}^{2}\end{array}$ & $\begin{array}{l}\text { Cell } \\
\text { temperature } \\
\text { in }{ }^{\mathrm{O}} \mathrm{C}\end{array}$ & $\begin{array}{l}\mathrm{V}_{\mathrm{dc}} \text { in } \\
\text { volts }\end{array}$ & $\begin{array}{l}\mathrm{V}_{\mathrm{r}} \text { in } \\
\%\end{array}$ & $\begin{array}{l}\mathrm{V}_{\alpha} \text { in } \\
\% /{ }^{\circ} \mathrm{C}\end{array}$ \\
\hline \multirow{3}{*}{$\begin{array}{l}\frac{0}{1} \\
\stackrel{1}{n} \\
\end{array}$} & $\begin{array}{l}X_{1}= \\
10: 16: 28\end{array}$ & $\begin{array}{l}\mathrm{POA}_{1}=733 \\
.01\end{array}$ & $\mathrm{~T}_{\mathrm{c} 1}=49.15$ & $\begin{array}{l}\mathrm{V}_{1}= \\
631.16\end{array}$ & 85.83 & \multirow{3}{*}{-0.378} \\
\hline & $X_{2}=12: 45$ & $\begin{array}{l}\mathrm{POA}_{2}=916 . \\
81\end{array}$ & $\mathrm{~T}_{\mathrm{c} 2}=59.97$ & $\begin{array}{l}V_{2}= \\
601.07\end{array}$ & 81.73 & \\
\hline & $\begin{array}{l}\Delta \mathrm{X}=\mathrm{X}_{2}-\mathrm{X}_{1} \\
=2: 30 \mathrm{hrs}\end{array}$ & $\begin{array}{l}\Delta \mathrm{POA}_{\mathrm{M}}= \\
183.8\end{array}$ & $\Delta \mathrm{T}_{\mathrm{cM}}=10.82$ & $\begin{array}{l}\Delta \mathrm{V}_{\mathrm{M}}= \\
-30.09\end{array}$ & $\begin{array}{l}\Delta \mathrm{V}_{\mathrm{uM}} \\
=-4.09\end{array}$ & \\
\hline \multirow{3}{*}{$\begin{array}{l}\frac{0}{1} \\
b \\
1 \\
\dot{y}\end{array}$} & $\begin{array}{l}X_{1}= \\
10: 13: 22\end{array}$ & $\begin{array}{l}\mathrm{POA}_{1}=854 \\
.87\end{array}$ & $\mathrm{~T}_{\mathrm{cl} 1}=49.03$ & $\begin{array}{l}\mathrm{V}_{1}= \\
629.10\end{array}$ & 85.56 & \multirow{3}{*}{-0.43} \\
\hline & $\begin{array}{l}X_{2}= \\
13: 11: 31\end{array}$ & $\begin{array}{l}\mathrm{POA}_{2}= \\
991.92\end{array}$ & $\mathrm{~T}_{\mathrm{c} 2}=59.47$ & $\begin{array}{l}\mathrm{V}_{2}= \\
596.04\end{array}$ & 81.05 & \\
\hline & $\begin{array}{l}\Delta \mathrm{X}=\mathrm{X}_{2}-\mathrm{X}_{1} \\
=3: 00 \mathrm{hrs}\end{array}$ & $\begin{array}{l}\Delta \mathrm{POA}_{\mathrm{j}}= \\
137.05\end{array}$ & $\Delta \mathrm{T}_{\mathrm{cj}}=+10.44$ & $\begin{array}{l}\Delta \mathrm{V}_{\mathrm{j}}= \\
-33.06\end{array}$ & $\begin{array}{l}\Delta \mathrm{V}_{\mathrm{uj}}= \\
-4.49\end{array}$ & \\
\hline \multirow{3}{*}{$\begin{array}{l}\frac{6}{1} \\
\frac{1}{2} \\
=\end{array}$} & $\begin{array}{l}X_{1}= \\
10: 59: 50\end{array}$ & $\begin{array}{l}\mathrm{POA}_{1}= \\
797.60\end{array}$ & $\mathrm{~T}_{\mathrm{cl} 1}=50.78$ & $\begin{array}{l}V_{1}= \\
629.24\end{array}$ & 85.56 & \multirow{3}{*}{-0.487} \\
\hline & $\begin{array}{l}X_{2}= \\
12: 58: 36\end{array}$ & $\begin{array}{l}\mathrm{POA}_{2}= \\
899.81\end{array}$ & $\mathrm{~T}_{\mathrm{c} 2}=55.15$ & $\begin{array}{l}V_{2}= \\
613.57\end{array}$ & 83.36 & \\
\hline & $\begin{array}{l}\Delta \mathrm{X}=\mathrm{X}_{2}-\mathrm{X}_{1} \\
=2: 00 \mathrm{hrs}\end{array}$ & $\begin{array}{l}\Delta \mathrm{POA}_{\mathrm{J}}= \\
102.21\end{array}$ & $\Delta \mathrm{T}_{\mathrm{cJ}}=+4.37$ & $\begin{array}{l}\Delta \mathrm{V}_{\mathrm{J}}= \\
-15.67\end{array}$ & $\begin{array}{l}\Delta \mathrm{V}_{\mathrm{uJ}}= \\
-2.13\end{array}$ & \\
\hline \multicolumn{2}{|c|}{ Average } & $\begin{array}{l}\Delta \mathrm{POA}_{\mathrm{a}}= \\
+141.07\end{array}$ & $\Delta \mathrm{T}_{\mathrm{ca}=+} 8.94$ & $\begin{array}{l}\Delta \mathrm{V}_{\mathrm{a}}= \\
-26.27\end{array}$ & $\begin{array}{l}\Delta \mathrm{V}_{\text {ua }} \\
=-3.56\end{array}$ & -0.431 \\
\hline
\end{tabular}

\subsection{Effect of comparatively lower cell temperature}

To compare effect of high and low cell temperature graphs corresponding to relatively different temperature for the month of October, December, February and April have been compiled in figure 6. In the month of December, November and January the maximum cell temperature is less than $45^{\circ} \mathrm{C}$, the result is that $\mathrm{V}_{\mathrm{dc}}$ does not reach point of saturation and hence does not attain constant value as shown only for the month of December in figure 6. For the month when cell temperature is low, duration for which $\mathrm{V}_{\mathrm{dc}}$ remains constant reduces as is evident for the month of February in figure 6. As temperature increases both the value of $\mathrm{dc}$ voltage and duration for which it remains constant increases correspondingly as is evident from the figure 6 by the gradually increased duration for the month of February, October and April respectively clearly showing overall positive effect of high cell temperature despite slight negative temperature coefficient above $49^{\circ} \mathrm{C}$.

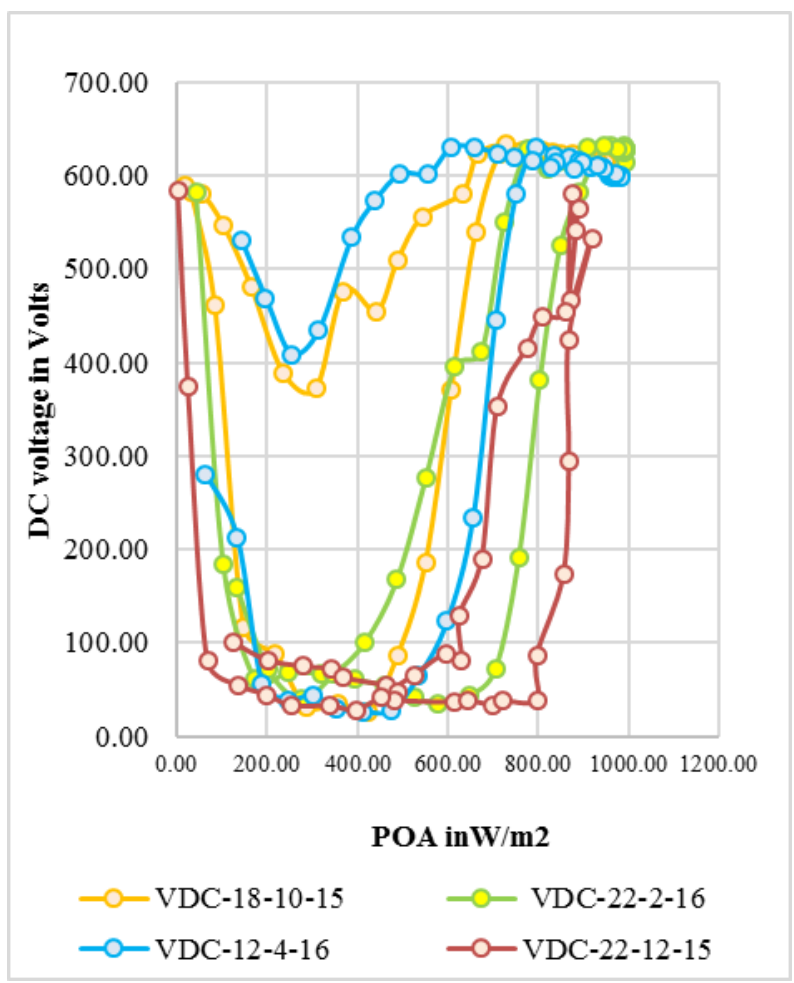

Figure 6- Variation of de voltage for specific daysOctober $\left(18^{\text {th }}\right)$, December $\left(22^{\text {nd }}\right)$, February $\left(22^{\text {nd }}\right)$ and April (12 $\left.{ }^{\text {th }}\right)$

3.3 Effect of extremely low temperature Effect of very low cell temperature in the range of $20-41{ }^{\circ} \mathrm{C}$ is explained vide figure 7 


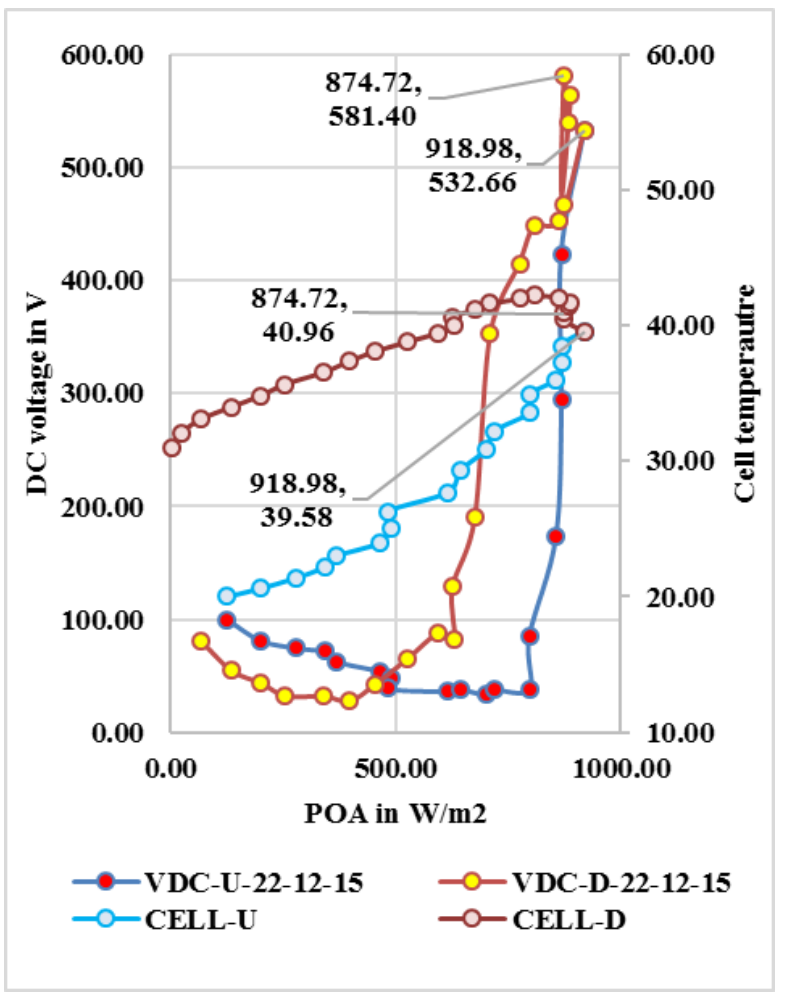

Figure 7- Variation of $V_{d c}$ and cell temperature with POA for 22-12-2015

$\mathrm{V}_{\mathrm{dc}}$ in the range of $60-75 \%$ of its maximum rated value is obtained for very short duration of about two hours. It can be observed that maximum $\mathrm{V}_{\mathrm{dc}}$ in the month of December is only $581.40 \mathrm{~V}$ that too only once at cell temperature $41.49^{\circ} \mathrm{C}$, POA $874.72 \mathrm{~W} / \mathrm{m}^{2}$, while at POA $918.98 \mathrm{~W} / \mathrm{m}^{2}$, cell temperature $39.5^{\circ} \mathrm{C}, \mathrm{V}_{\mathrm{dc}}$ is only $532.66 \mathrm{~V}$, clearly showing higher $\mathrm{dc}$ voltage at higher cell temperature. Comparing it with month of June much higher dc voltage $629.24 \mathrm{~V}$ is obtained at cell temperature $50.78{ }^{\circ} \mathrm{C}$ and $613.57 \mathrm{~V}$ at cell temperature $55.15^{\circ} \mathrm{C}$. Thus, in contrast to existing literature which shows dc voltage decreases with increase in cell temperature above $25^{\mathrm{O}} \mathrm{C}$, the analysis of real field data for different temperatures especially for extreme temperatures clearly show positive effect of high cell temperature on a multicrystalline PV module.

\section{RESULT}

The analysis for three different random days of May, June and July has been shown, although the result is same for all days of these months, except for few days when data is not available either due to grid failure or some other problem. For the month when cell temperature is below $45^{\circ} \mathrm{C}, \mathrm{V}_{\mathrm{dc}}$ does not reach saturation and constant value is not maintained. The temperature coefficient is calculated on the basis that there is linear decrease in $\mathrm{V}_{\mathrm{dc}}$ with linear increase in cell temperature for three different days and the average value of three different days is shown in table 2 . With reference to $13^{\text {th }}$ May, as shown in figure 5 and table 2 , one can clearly see that $V_{d c}$ decreases linearly from $631.16 \mathrm{~V}$ to $601.07 \mathrm{~V}$ as cell temperature increases linearly from $49.15^{\circ} \mathrm{C}$ to $59.97^{\circ} \mathrm{C}$. The corresponding percentage reduction in $\mathrm{V}_{\mathrm{dc}}$ with respect to maximum rated voltage is $\{(631.16-601.07) / 735.36\} * 100=$ $4.09 \%$; the corresponding increase in cell temperature is 59.97 $-49.15=10.82{ }^{\circ} \mathrm{C}$; the resulting temperature coefficient is $4.09 / 10.82=-0.378 \% /{ }^{\circ} \mathrm{C}$ as shown in table 2. Similarly, temperature coefficient for $4^{\text {th }}$ June and $11^{\text {th }}$ July are $-0.43 \% /$ ${ }^{\circ} \mathrm{C}$ and $-0.487 \% /{ }^{\circ} \mathrm{C}$ respectively. The average temperature coefficient of three days is $-(0.378+0.43+0.487) / 3=-$ $0.431 \% /{ }^{\circ} \mathrm{C}$ for cell temperature greater than $49^{\circ} \mathrm{C}$ in contrast to $25^{\circ} \mathrm{C}$ cited in literature. Further environmental conditions vary from place to place and is different in different seasons even at the same place. In Western Rajasthan in summer season(April-July) the cell temperature is as high as $50.78^{\circ} \mathrm{C}$ even when POA is only $797.60 \mathrm{~W} / \mathrm{m}^{2}$ and reaches about $60^{\circ} \mathrm{C}$ for POA equal to $992 \mathrm{~W} / \mathrm{m}^{2}$, while in the month of December the cell temperature is only $39.58^{\circ} \mathrm{C}$ for $\mathrm{POA}$ equal to $918.98 \mathrm{~W} / \mathrm{m}^{2}$. It is observed that $\mathrm{V}_{\mathrm{dc}}$ attains point of saturation only at high temperature. The point of saturation for $\mathrm{dc}$ voltage is the point at which $\mathrm{V}_{\mathrm{dc}}$ attains $85 \%$ of its maximum rated value and thereafter maintains nearly constant value within $80-85 \%$ even though POA drops to as low as $250 \mathrm{~W} / \mathrm{m}^{2}$. Further $\mathrm{V}_{\mathrm{dc}}$ at cell temperature $39.58{ }^{\circ} \mathrm{C}$, POA equal to $918.98 \mathrm{~W} / \mathrm{m}^{2}$ is only $532.6 \mathrm{~V}$, whereas much higher $\mathrm{V}_{\mathrm{dc}}(629.24 \mathrm{~V})$ is obtained at higher cell temperature of $50.78^{\circ} \mathrm{C}$, POA $797.60 \mathrm{~W} / \mathrm{m}^{2}$. Slight negative temperature coefficient is observed for cell temperature greater than $49^{\circ} \mathrm{C}$, but still $\mathrm{V}_{\mathrm{dc}}$ even at $60^{\circ} \mathrm{C}$ cell temperature is far greater than $\mathrm{V}_{\mathrm{dc}}$ at $25^{\circ} \mathrm{C}$ showing overall positive effect of high temperature.

\section{CONCLUSION}

The negative temperature coefficient for $\mathrm{V}_{\mathrm{dc}}$ calculated for the real field data of a grid connected multicrystalline $\mathrm{PV}$ power plant of Western Rajasthan is about $-0.431 \% /{ }^{\circ} \mathrm{C}$ for cell temperature greater than $49^{\circ} \mathrm{C}$ in contrast to $25^{\circ} \mathrm{C}$ mentioned in literature. Another noteworthy feature is that with decrease in POA, cell temperature also starts reducing, the result is that $\mathrm{V}_{\mathrm{dc}}$ start increasing, maintaining nearly high constant value in the range of $80-85 \%$ of its maximum value. DC voltage obtained at high cell temperature $49-60^{\circ} \mathrm{C}$ is much greater than voltage at $25-40{ }^{\circ} \mathrm{C}$ even at lower irradiance, showing overall high cell temperature has positive impact on a multicrystalline module.

Thus, this paper besides evaluating DC voltage temperature coefficient of a multicrystalline module in real field conditions, brings forward a vital fact that PV plant should be operated at cell temperature greater than $45^{\circ} \mathrm{Cto}$ attain $\mathrm{dc}$ output voltage in the range of $80-85 \%$ of its maximum rated value. As to dc voltage has positive effect at high cell temperature and current has positive temperature coefficient, operating a multicrystalline power plant at high POA and high cell temperature will give higher efficiency. Western Rajasthan has high cell temperature and high irradiance for about 7 hours for more than eight months, high dc voltage $(80-85 \%)$ for about $(7 * 8 * 30=1680$ hours $)$ in a year is obtained provided proper grid evacuation is ensured. Thus, Western Rajasthan has the capability to become world leader in the field of solar energy. As further work the temperature coefficient needs to be re-evaluated considering average of all possible values over a period of at least one or five years and effect of high cell temperature on the power output needs to analysed. Also, analysis for different types of cell in different environmental conditions needs to be done.

\section{ACKNOWLEDGMENT}

The authors would like to acknowledge the support of Shri J. K. Borgohain, Executive Director, Rajasthan Project. Oil India Lmt., Jodhpur, Shri D. C. Gogoi, Head, Technical Service, Oil India Lmt, Jodhpur; Shri Rajesh Kundoo, 
Incharge, PV Power Plant at Ramgarh, Jaisalmer in conducting this study.

\section{REFERENCES}

[1] Thevenard. D, Richmond, BC, "Review and recommendations for improving the modelling of building integrated photovoltaic systems", Ninth International IBPSA Conference, Montréal, Canada, August 15-18, 2005.

[2] Masters, G. M. 2004. Renewable and efficient electric power systems. Wiley Inter science.

[3] www.mapsofindia.com > Maps > Rajasthan > Geography History

[4] Garg, S. and JB, Arun. 2016. High Temperature Effect on Multicrystalline Photovoltaic Module in Western Rajasthan, India. Communications on Applied Electronics (CAE) - ISSN: 2394-4714 Foundation of Computer Science FCS, New York, USA, Volume 4 No.2, January 2016 - www.caeaccess.org.

[5] Garg, S. JB, Arun. and D. C. Surana 2016. Performance of a Multicrystalline Photovoltaic Module in Critical Climatic Conditions of Western Rajasthan, India. Communications on Applied Electronics (CAE) - ISSN: 2394-4714Foundation of Computer Science FCS, New York, USA, Volume 5- No.4, June 2016 www.caeaccess.org

[6] Mayfield, R. 2010. Photovoltaic design and installation for dummies. Wiley Publishing Inc.

[7] Babatunde, A.A, Abbasoglu, S. Evaluation of field data and simulation results of a photovoltaic system in countries with high solar radiation. Turkish Journal of Electrical Engineering \& Computer Sciences.

[8] Kozak, T. Maranda, W. Napieralski, A. Mey, G. D. and Vos, A. D. 2009. Influence of Ambient Temperature on the Amount of Electric Energy Produced by Solar
Modules. 16th International Conference on Mixed Design of Integrated Circuits and Systems, Poland.

[9] N. Ciprian, M. Florin, A. Dragos. Annual Energy harvest of LACARP photovoltaic Systems. 6th International conference on modern Power systems MPS 2015, 18-21 May 2015, Cluj -Napoca, Romanic.

[10] E. Radziemska. The effect of temperature on the power drop in crystalline silicon solar cells Renewable Energy 28 (2003) 1-12, www.elsevier.com/locate/renene.

[11] B. Verhelst, D. Caes, L. Vandevelde, Senior Member IEEE, J. Desmet, Senior Member IEEE. Prediction of Yield of solar modules as a function of technological and climatic parameters.

[12] Bhattacharya, T. Chakraborty, A.K and Pal, K. Effects of Ambient Temperature and Wind Speed on Performance of Monocrystalline Solar Photovoltaic Module in Tripura, India. Hindawi Publishing Corporation Journal of Solar Energy Volume 2014, Article ID 817078, 5 pages. http://dx.doi.org/10.1155/2014/817078.

[13] Panagea, S.I, Tsanis, K.I Koutroulis ,G.A. and. Grillakis,G.M. Climate Change Impact on Photovoltaic Energy Output: The Case of Greece. Hindawi Publishing Corporation Advances in Meteorology Volume 2014, Article ID 264506, 11 pages http://dx.doi.org/10.1155/2014/264506.

[14] Dincer, F. and Meral, M.E. Critical factors that affecting efficiency of Solar Cell. Smart Grid and Renewable Energy, 2010,1,47-50.

[15] Majid, S.S. Jassim Mohammed, N.J. Mohammed, S. Practical Evaluation of Solar Irradiance Effect on PV Performance. Energy Science and Technology Vol. 6, No. 2, 2013, pp. 36-40.

[16] Rekioua, D. Matange 2012. Optimization of Photovoltaic power systems Modelization, Simulation and Control. http://www.springer.com/978-1-4471-2348-4 